\title{
How Is the COVID-19 Outbreak Affecting Wildlife around the World?
}

\author{
Abdel Fattah N. Abd Rabou \\ Department of Biology, Faculty of Science, Islamic University of Gaza, Gaza Strip, Palestine \\ Email: arabou@iugaza.edu.ps
}

How to cite this paper: Abd Rabou, A.N. (2020) How Is the COVID-19 Outbreak Affecting Wildlife around the World? Open Journal of Ecology, 10, 497-517. https://doi.org/10.4236/oje.2020.108032

Received: June 2, 2020

Accepted: August 1, 2020

Published: August 4, 2020

Copyright $\odot 2020$ by author(s) and Scientific Research Publishing Inc. This work is licensed under the Creative Commons Attribution International License (CC BY 4.0).

http://creativecommons.org/licenses/by/4.0/ (c) (i) Open Access

\begin{abstract}
The COVID-19 is the infectious disease caused by the most recently discovered coronavirus at an animal market in Wuhan, China. Many wildlife species have been suggested as possible intermediate sources for the transmission of COVID-19 virus from bats to humans. The quick transmission of COVID-19 outbreak has imposed quarantine measures across the world, and as a result, most of the world's towns and cities fell silent under lockdowns. The current study comes to investigate the ways by which the COVID-19 outbreak affects wildlife globally. Hundreds of internet sites and scientific reports have been reviewed to satisfy the needs of the study. Stories of seeing wild animals roaming the quiet, deserted streets and cities during the COVID-19 outbreak have been posted in the media and social media. The strong link between wildlife markets and COVID-19 resulted in international calls asking countries to shut down wildlife markets forever. Poorer and vulnerable people around the world overexploit natural resources including wildlife. Roadkills became minimal because of the lockdown measures. The reduction in noise pollution level is expected to improve wildlife health and ecology including breeding success. The shortage of food items provided to zoo and park animals constituted a real threat to animals and the institution harboring them. The increase in fish biomass comes as a result of the sharp decline in fishing activities. The isolation of antibodies from certain wildlife species is promising in saving humankind against COVID-19. The infection of wild and pet animals with COVID-19 virus from humans and the interspecific transmission of the infection are disastrous to animal ecology. Finally, closures may enhance people to connect more and more with nature in order to acknowledge wildlife in their surrounding environments. In conclusion, the study asks the world's different parties to conserve wildlife in a sustainable fashion and to regulate exotic animal trade in wet markets in order to lower the incidence of zoonoses.
\end{abstract}




\section{Keywords}

COVID-19, Coronavirus, Outbreak, Wildlife, Wildlife Markets, China

\section{Introduction}

Coronaviruses are a large family (Coronaviridae) of single-stranded RNA (ribonucleic acid) viruses that have a lipid envelope studded with club-shaped projections, which may cause illnesses in wildlife and domestic animals (especially birds and mammals) or humans [1] [2] [3]. Some strains of coronaviruses are zoonotic; meaning they can be transmitted between animals and humans, but many strains are not zoonotic. In humans, several coronaviruses are known to cause severe respiratory diseases such as the Middle East respiratory syndrome (MERS) and the severe acute respiratory syndrome (SARS) [4] [5]. The coronavirus disease-19 (COVID-19) is an infectious disease caused by the most recently discovered coronavirus. The first transmissions of COVID-19 from animals to humans are said to have taken place at an animal market in Wuhan, China. COVID-19 was unknown before the outbreak began in Wuhan, China, in December 2019 [3] [6] [7].

Wildlife is a term that refers to all life forms of plants and animals that live in all ecosystems and do not depend directly on humans for their livelihood. Wildlife plays a vital role in human being life, providing cultural, medicinal, esthetic values and act as bioindicators [4]. Nowadays, the world is dealing with unprecedented threats to wildlife. The loss of habitat from farming, mining and new urban developments has dramatically decreased the natural space for wildlife. Climate change, pollution and introduction of invasive species are also threatening factors. Illegal wildlife trade continues to pose a real danger to biodiversity, ecosystems and human health, as a number of emerging diseases stem from animal products, both domestic and wild [8] [9].

Human interactions with wildlife can be a source of zoonoses or animal-based diseases [10] [11]. It is well known that people who have close contact with domestic or wild animals at home, zoo and nature can be subject to zoonotic diseases. Zoonoses account for an estimated $73 \%$ of all emerging infectious diseases affecting humans. Many wildlife species (especially wild mammals) were known to be associated with coronaviruses [1] [4] [12]. For example, the SARS coronavirus was associated with Civet Cats and the MERS coronavirus was transmitted by Dromedary Camels [5]. The COVID-19 virus isolated from humans shares $96 \%$ homology with beta coronaviruses isolated from multiple species of bats in the genus Rhinolophus. Bats belonging to this genus are widely distributed across Asia, the Middle East, Africa and Europe. How did the COVID-19 virus appear and spread from bat to human? This question still worries the scientists and researchers worldwide [3]. Although there is a wide dialogue that COVID-19 is thought to have originated in bats, the intermediate ani- 
mal sources of the virus are completely unknown [2]. China is home for several farms that rear several animal species such as deer, snakes, porcupines, foxes, civets, bears, turtles, bamboo rats, mink, and birds. Such farms can be targeted to find the origin of COVID-19 [13]. Many wild animals have been strongly suggested by many scientific parties as possible intermediate sources for the transmission of COVID-19 virus from bats to humans (Table 1 and Figure 1).
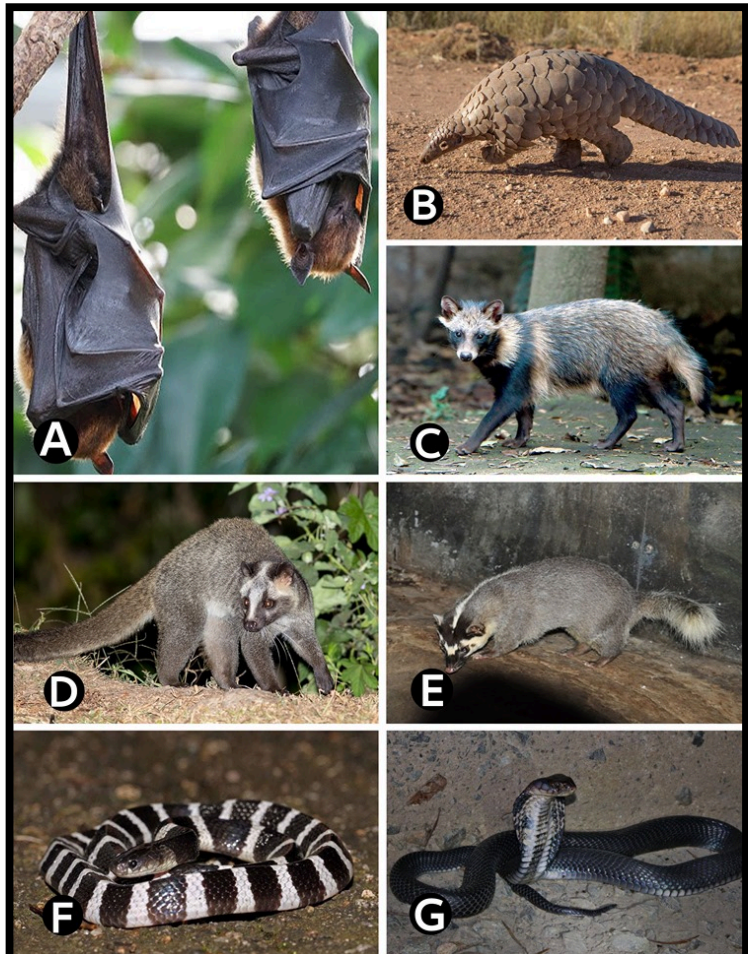

Figure 1. Wild mammals suggested as a missing link for transmission of COVID-19 virus from bats in the genus Rhinolophus to humans: (A) Horseshoe Bat (Rhinolophus affinis), (B) Malayan Pangolin or Scaly Anteater (Manis javanica), (C) Racoon Dog (Nyctereutes procyonoides), (D) Masked Palm Civet (Paguma larvata), (E) Chinese Ferret-badger (Melogale moschata), (F) Chinese or Many-banded Krait (Bungarus multicinctus), and (G) Chinese Cobra (Naja atra) [The photos were taken from different internet sources including the Wikipedia, 2020].

Table 1. Wild animals considered as a missing link for transmission of COVID-19 virus from bats to humans.

\begin{tabular}{cccc}
\hline Order & Family & Common Name & Scientific Name \\
\hline Pholidota & Manidae & Malayan Pangolin & Manis javanica \\
& Canidae & Raccoon Dog & Nyctereutes procyonoides \\
Carnivora & Viverridae & Masked Palm Civet & Paguma larvata \\
& Mustelidae & Chinese Ferret-badger & Melogale moschata \\
& & Chinese Krait & Bungarus multicinctus \\
Squamata & Elapidae & Chinese Cobra & Naja atra \\
\hline
\end{tabular}


Scientists think that the Malayan Pangolin or Scaly Anteater (Manis javanica), may be the missing link for transmission of COVID-19 from bats; especially the Horseshoe Bats (Rhinolophus affinis), to humans [14] [15]. Pangolins are the most illegally traded and most trafficked mammals in the world [16] [17]. They are prized for their meat and the claimed medicinal properties of their scales [18] [19] [20] [21]. There are many theories claiming the transmission of COVID-19 virus from the bats to the Raccoon Dog (Nyctereutes procyonoides), Masked Palm Civet (Paguma larvata) or the Chinese ferret-badger (Melogale moschata) and from them to humans. In addition to these mammalian species, snakes; notably the Chinese or Many-banded Krait (Bungarus multicinctus) and the Chinese or Taiwan Cobra (Naja atra), were also said as the original source of COVID-19 virus. The last conclusion was quickly ignored, partly because there was no previous evidence that coronaviruses can jump from a cold-blooded animal, such as snakes, to human beings [22].

As quarantine measures take hold across the world because of COVID-19 outbreak which started in December, 2019, the towns, cities and even the rural areas in most countries fell silent. The indoor situation of most people made these places calm. The wildlife harboring the various ecosystems like forests, jungles, coastal areas, ponds, agricultural fields usually aware of its surrounding environment; noticing and responding. In fact, COVID-19 outbreak affects wildlife around the world in several ways. Hence, the current study comes to investigate the different effects does the current COVID-19 outbreak impose on wildlife globally. The importance of the study comes from the fact that it is probably unique in its kind in times the current researches focus on the medical issues related to COVID-19.

\section{Methods}

This study depends mostly on media and posts of social media concerning wild animals that have been affected by COVID-19 outbreak and the associated quarantine measures. From the beginning of the COVID-19 outbreak, the author continued the fellow up of all news and issues associated with the outbreak. Several Arabic and English news and scientific websites have been reviewed to meet the study needs.

\section{Results \& Discussion}

The continual reviews of internet sites on how the current COVID-19 outbreak affects wildlife around the world were of great importance in giving a whole picture. The coming paragraphs, tables and photos point out much of the ecological effects of COVID-19 outbreak on wild animals around the world.

\subsection{Opportunistic Wildlife Occurring at Urban Places}

In most countries of the world extending from the East to the West, people have been told to stay at home to try and stop the spread of COVID-19 outbreak. As a result of this lockdown and these quarantine measures, a lot of wild animal spe- 
cies that live in cities or on their outskirts were seen by local people and stakeholders exploring or invading the empty streets, roads and parks in search of food or just to play [23] [24] [25]. The phenomenon is worldwide. People on lockdown have been posting on social media with stories of seeing wild animals roaming the quiet, deserted streets and cities during the COVID-19 outbreak. The examples are rich: The Kashmiri or Mountain Goats (Capra falconeri) roamed the streets and parks of Wales, Britain. Wild Boars (Sus scrofa) invaded the streets of many cities like Paris (France), Barcelona (Spain) and Haifa (Israel). The strange Small Indian Civet (Viverricula indica), which is a common carnivore in southeastern Asia [26], was seen roaming the streets of New Delhi (India). Agence France-Presse [23] has reported a Sika Deer (Cervus nippon) roaming through metro stations of Nara, Japan. Gangs of Wild Turkeys (Meleagris gallopavo) strut through Oakland in California, USA. The Puma or Cougar (Puma concolor) finds its way to the center of Santiago, Chile. In certain circumstances, these opportunistic invading wild animals may raid crops, attack livestock, and even kill people. Table 2 and Figure 2 illustrate a group of wildlife species (mammals, birds and reptiles) that were seen invading the empty, deserted cities and towns worldwide.

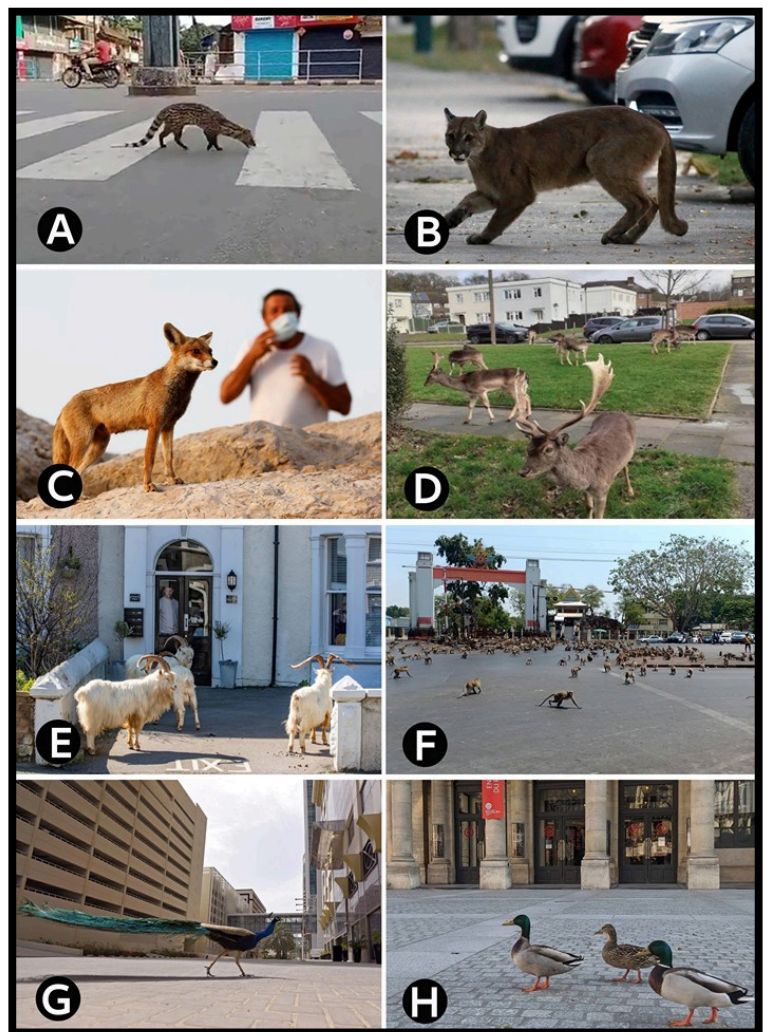

Figure 2. Examples of wildlife species taking over the streets and roads as an advantage of the deserted cities worldwide, imposed by the COVID-19 outbreak: (A) Small Indian Civet (Viverricula indica), (B) Puma (Puma concolor), (C) Red Fox (Vulpes vulpes), (D) Fallow Deer (Dama dama), (E) Kashmiri Goat (Capra falconeri), (F) Macaque (Macaca sylvanus), (G) Indian Peacock (Pavo cristatus), and (H) Mallard (Anas platyrhynchos) [The photos were taken from different internet sources]. 
Table 2. A selected list of wildlife species invading and roaming the empty cities worldwide during COVID-19 outbreak.

\begin{tabular}{|c|c|c|c|c|}
\hline Class & Order & Common Name & Scientific Name & Location(s) \\
\hline & & Coyote & Canis latrans & $\begin{array}{l}\text { San Francisco, USA } \\
\text { Los Angeles, USA }\end{array}$ \\
\hline & & Bear & Ursus arctos californicus & California, USA \\
\hline & & Small Indian Civet & Viverricula indica & Kerala, India \\
\hline & & Puma (Cougar) & Puma concolor & Santiago, Chile \\
\hline & & Sea Wolf & Zalophus wollebaeki & $\begin{array}{c}\text { Galapagos Islands, } \\
\text { Ecuador }\end{array}$ \\
\hline & Carnivora & River Otter & Lutrogale perspicillata & $\begin{array}{l}\text { Marina Bay, } \\
\text { Singapore }\end{array}$ \\
\hline & & North American Raccoon & Procyon lotor & $\begin{array}{c}\text { San Felipe, Panamá } \\
\text { New York, USA }\end{array}$ \\
\hline & & Golden Jackal & Canis aureus & Tel Aviv, Israel \\
\hline & & Red Fox & Vulpes vulpes & $\begin{array}{l}\text { West Bank, Palestine } \\
\text { Ashkelon, Israel }\end{array}$ \\
\hline & & South American Sea Lion & Otaria flavescens & Buenos Aires, Argentina \\
\hline & & Capybara & Hydrochoerus hydrochaeris & Buenos Aires, Argentina \\
\hline & Rodentia & Nutria (Coypu or Swamp Rat) & Myocastor coypus & Milano, Italy \\
\hline & & Eastern Gray Squirrel & Sciurus carolinensis & $\begin{array}{c}\text { California, USA } \\
\text { Milano, Italy }\end{array}$ \\
\hline \multirow{16}{*}{$\begin{array}{l}\text { Mammalia } \\
\text { (Mammals) }\end{array}$} & Lagomorpha & European Rabbit & Oryctolagus cuniculus & $\begin{array}{l}\text { Christchurch, } \\
\text { New Zealand }\end{array}$ \\
\hline & & Water Buffalo & Bubalus bubalis & New Delhi, India \\
\hline & & Kashmiri or Mountain Goat & Capra falconeri & Wales, Britain \\
\hline & & & & $\begin{array}{c}\text { Barcelona, Spain } \\
\text { Paris, France }\end{array}$ \\
\hline & & Wild boar & Sus scrofa & $\begin{array}{l}\text { Ajaccio, Corsica } \\
\text { Haifa, Israel } \\
\text { Sassari, Sardinia }\end{array}$ \\
\hline & & Sika Deer (Japanese Deer) & Cervus nippon & Nara, Japan \\
\hline & Artiodactyla & Fallow Deer & Dama dama & London, Britain \\
\hline & & European Roe Deer & Capreolus capreolus & Zakopane, Poland \\
\hline & & Arabian Sand Gazelle & Gazella marica & Dubai, UAE \\
\hline & & Spotted Deer (Chital or Axis Deer) & Axis axis & Tirupati, India \\
\hline & & Blue Bull (Niglar) & Boselaphus tragocamelus & Noida, India \\
\hline & & Cow & Bos taurus & Delhi, India \\
\hline & & Arabian Camel (Dromedary) & Camelus dromedarius & Dubai, UAE \\
\hline & Perissodactyla & Indian Rhinoceros & Rhinoceros unicornis & Sonapur, Guwahati \\
\hline & & Grey Langur (Hanuman Langur) & Semnopithecus entellus & Ahmadabad, India \\
\hline & Primates & Macaque & Macaca sylvanus & Lopburi, Thailand \\
\hline
\end{tabular}




\section{Continued}

\begin{tabular}{ccccc}
\hline \multirow{2}{*}{ Aves (Birds) } & Charadriiformes & Black-headed Gull & Chroicocephalus ridibundus & Paris, France \\
& Pelecaniformes & White Pelican & Pelecanus erythrorhynchos & Paris, France \\
& Galliformes & Indian or Blue Peacock & Pavo cristatus & Ronda, Spain \\
Dubai, UAE
\end{tabular}

\subsection{Preventing and Stopping Illegal Trade in Wildlife}

China is one of the largest consumers of wild animals for food and traditional Chinese medicine in the world. A large volume of illegal trade has been recorded in the various cities of the country [27] [28]. In a modest study, Chow et al. [29] revealed the selling of 97 animal species distributed among reptiles, birds and mammals. Reptiles; particularly turtles, were the most commonly traded wild animals in China's wildlife markets. The Wuhan Market, for example, had a wild animal section where live and slaughtered species were for sale: snakes, beavers, porcupines, and baby crocodiles, among other animals. The sold animals originated not only from China but also Southeast Asia. Table 3 and Figure 3 illustrate a list of wildlife species sold at different wildlife markets in China; particularly the Wuhan Market. The COVID-19 outbreak, which likely originated at Wuhan Market selling wild animals in China, is a watershed moment for curbing the global wildlife trade, which can drive extinction and spread disease. Chinese farmers used to collect wild animals such as rats, civets, snakes, bats and others, and breed them for home consumption.

The overexploitation of wildlife through hunting and trade had led to an increase in infectious animal diseases that could spread between humans. Moreover, as natural habitats of wildlife diminish because of anthropogenic factors, wildlife closely approaches people, and this, in turn, accelerates the outbreak of diseases in wildlife and puts humans at risk of epidemics. Accordingly, many international calls have asked China and other countries to shut down wild animal markets forever, because of the strong link between those markets and the spread of zoonotic diseases. It was believed that the COVID-19 virus killed hun- 
dreds of thousands and infected millions of people till now. Humane Society International recommends that all countries with wildlife markets (including those selling live wild animals or their parts for food, pets, or other purposes) permanently ban, or severely limit, wildlife trade, transport and consumption. This ban should also apply to import, export and internal transport of live wildlife or wildlife meat intended for sale in wildlife markets [30]. The ban is encouraging in helping to address the fact that massive Chinese demand is driving some species to extinction. In this regard, the Chinese authorities have excluded cats and dogs from an official list of edible animals, in preparation for enacting legislation to reduce wild animal husbandry for the purpose of preventing the transmission of viruses to humans, as was most likely the case with the new COVID-19 virus. Moreover, eating and selling bat and pangolin meat has been banned by officials in Gabon. The decision was made over fears related to the global COVID-19 outbreak, which is thought to stem from wild animal meat sold at a market in Wuhan, China [31].

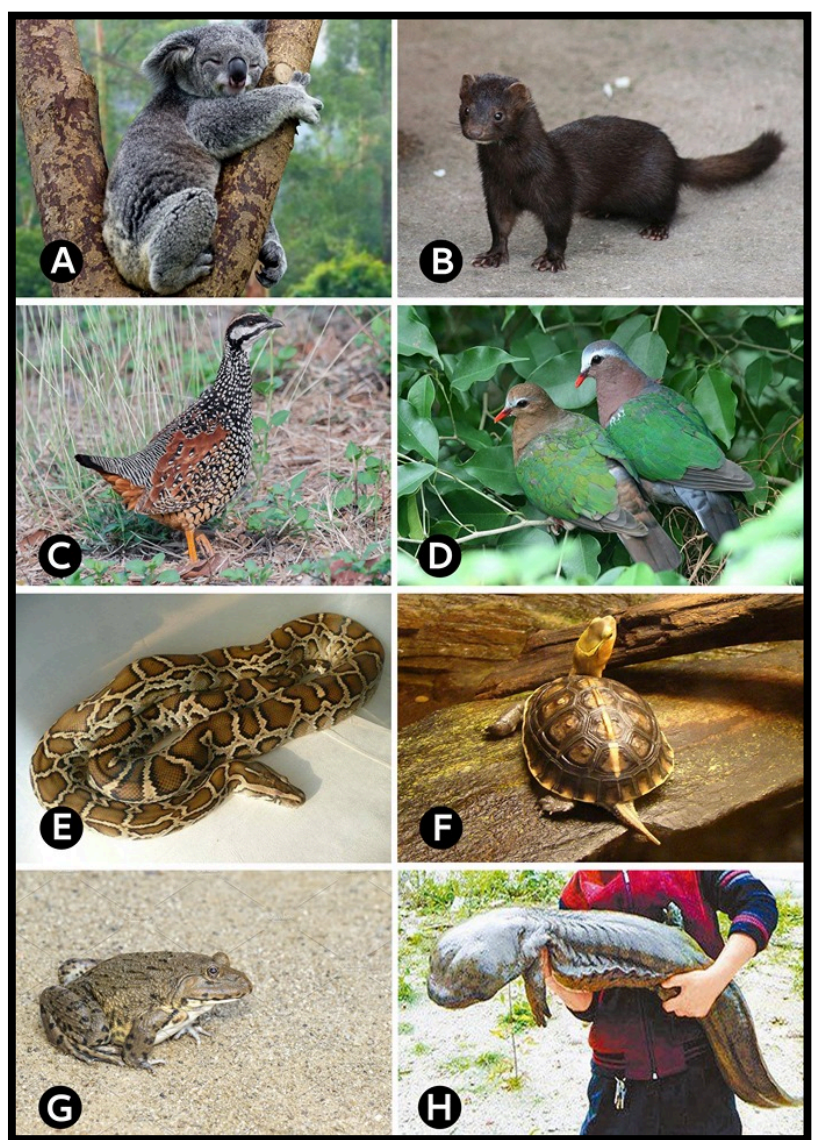

Figure 3. Examples of vertebrate wildlife species traded in China markets: (A) The marsupial Koala (Phascolarctos cinereus), (B) American Mink (Neovison vison), (C) Chinese Francolin (Francolinus pintadeanus), (D) Emerald Dove (Chalcophaps indica), (E) Burmese Python (Python molurus), (F) Chinese or Yellow-margined Box Turtle (Cuora flavomarginata), (G) Chinese Edible Frog (Hoplobatrachus rugulosus), and (H) Chinese Giant Salamander (Andrias davidianus) [The photos were taken from different internet sources including the Wikipedia, 2020]. 
Table 3. A collected list of wildlife species traded in China markets, particularly Wuhan Market, which is believed to be the source of COVID-19.

\begin{tabular}{|c|c|c|c|}
\hline Order & Family & Common Name & Scientific Name \\
\hline \multicolumn{4}{|c|}{ Class Mammalia } \\
\hline Diprotodontia & Phascolarctidae & Koala & Phascolarctos cinereus \\
\hline Lagomorpha & Leporidae & Chinese Hare & Lepus sinensis \\
\hline Pholidota & Manidae & Malayan Pangolin & Manis javanica \\
\hline \multirow{13}{*}{ Carnivora } & \multirow{3}{*}{ Canidae } & Raccoon Dog & Nyctereutes procyonoides \\
\hline & & Himalayan wolf & Canis lupus chanco \\
\hline & & Arctic or Polar Fox & Vulpes lagopus \\
\hline & \multirow{2}{*}{ Viverridae } & Masked Palm Civet & Paguma larvata \\
\hline & & Asian Palm Civet & Paradoxurus hermaphroditus \\
\hline & \multirow{6}{*}{ Mustelidae } & Chinese Ferret-badger & Melogale moschata \\
\hline & & American Mink & Neovison vison \\
\hline & & Hog Badger & Arctonyx collaris \\
\hline & & Eurasian or European Otter & Lutra lutra \\
\hline & & Asian Small-clawed Otter & Aonyx cinereus \\
\hline & & Smooth-coated Otter & Lutrogale perspicillata \\
\hline & Ursidae & Giant Panda & Ailuropoda melanoleuca \\
\hline & Sciuridae & Tarbagan Marmot & Marmota sibirica \\
\hline \multirow[t]{2}{*}{ Rodentia } & Hystricidae & Himalayan Porcupine & Hystrix brachyura \\
\hline & Spalacidae & Chinese Bamboo Rat & Rhizomys sinensis \\
\hline \multirow{4}{*}{ Artiodactyla } & \multirow{2}{*}{ Cervidae } & Spotted or Chital Deer & Axis axis \\
\hline & & Sika Deer & Cervus nippon \\
\hline & Bovidae & Tibetan antelope & Pantholops hodgsoni \\
\hline & Suidae & Wild Boar & Sus scrofa \\
\hline \multirow{5}{*}{ Chiroptera } & \multirow{3}{*}{ Pteropodidae } & Mariana Fruit Bat & Pteropus mariannus \\
\hline & & Small Mauritian Flying Fox & Pteropus subniger \\
\hline & & Guam Flying Fox & Pteropus tokudae \\
\hline & \multirow{2}{*}{ Rhinolophidae } & Chinese Horseshoe Bat & Rhinolophus sinicus \\
\hline & & Greater Horseshoe Bat & Rhinolophus ferrumequinum \\
\hline Eulipotyphla & Erinaceidae & Amur Hedgehog & Erinaceus amurensis \\
\hline \multicolumn{4}{|c|}{ Class Aves } \\
\hline Struthioniformes & Struthionidae & Common Ostrich & Struthio camelus \\
\hline \multirow[t]{2}{*}{ Falconiformes } & Falconidae & Saker Falcon & Falco cherrug \\
\hline & & Golden Pheasant & Chrysolophus pictus \\
\hline \multirow[t]{2}{*}{ Galliformes } & Phasianidae & Common Pheasant & Phasianus colchicus \\
\hline & & Hainan Peacock Pheasant & Polyplectron katsumatae \\
\hline
\end{tabular}




\section{Continued}

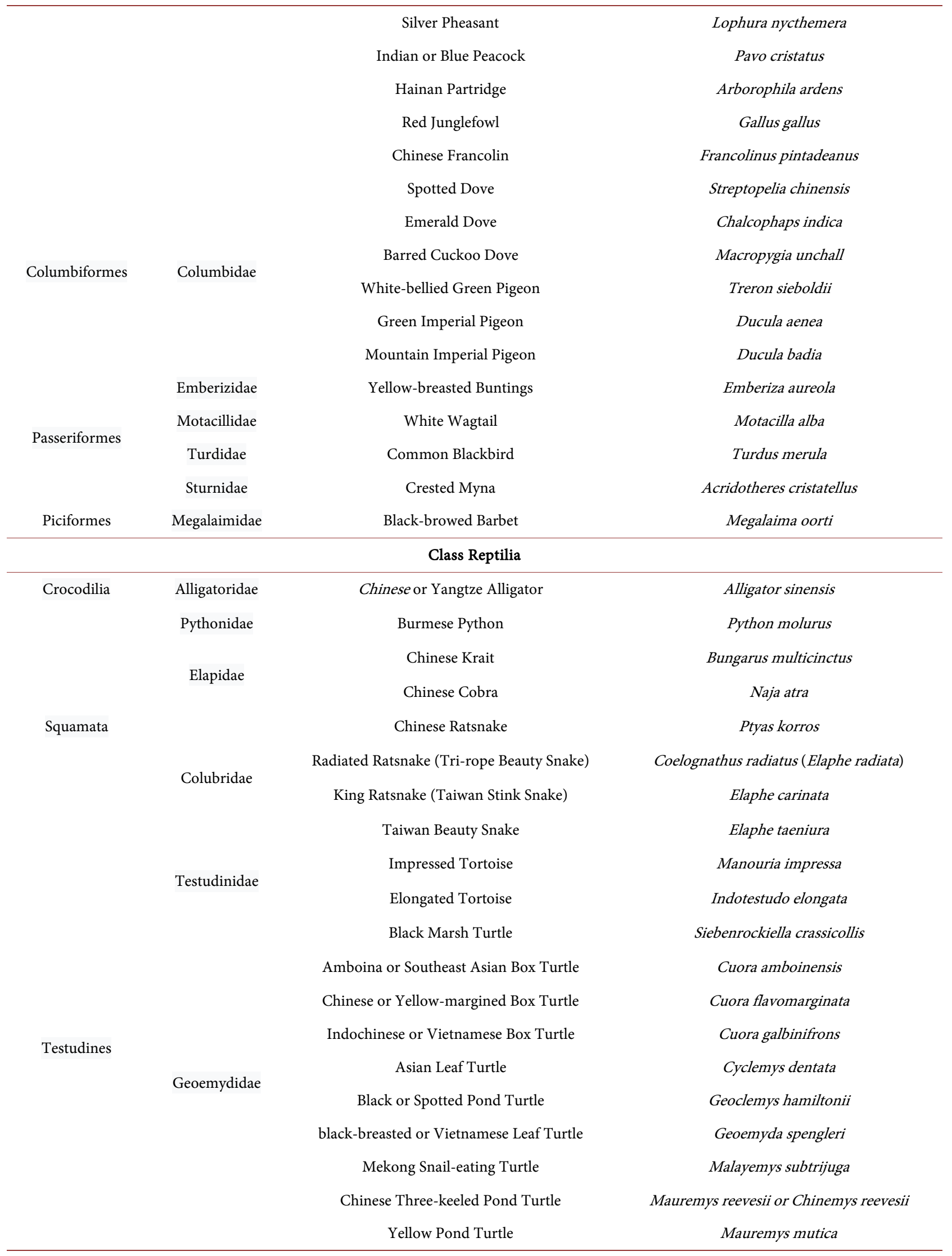




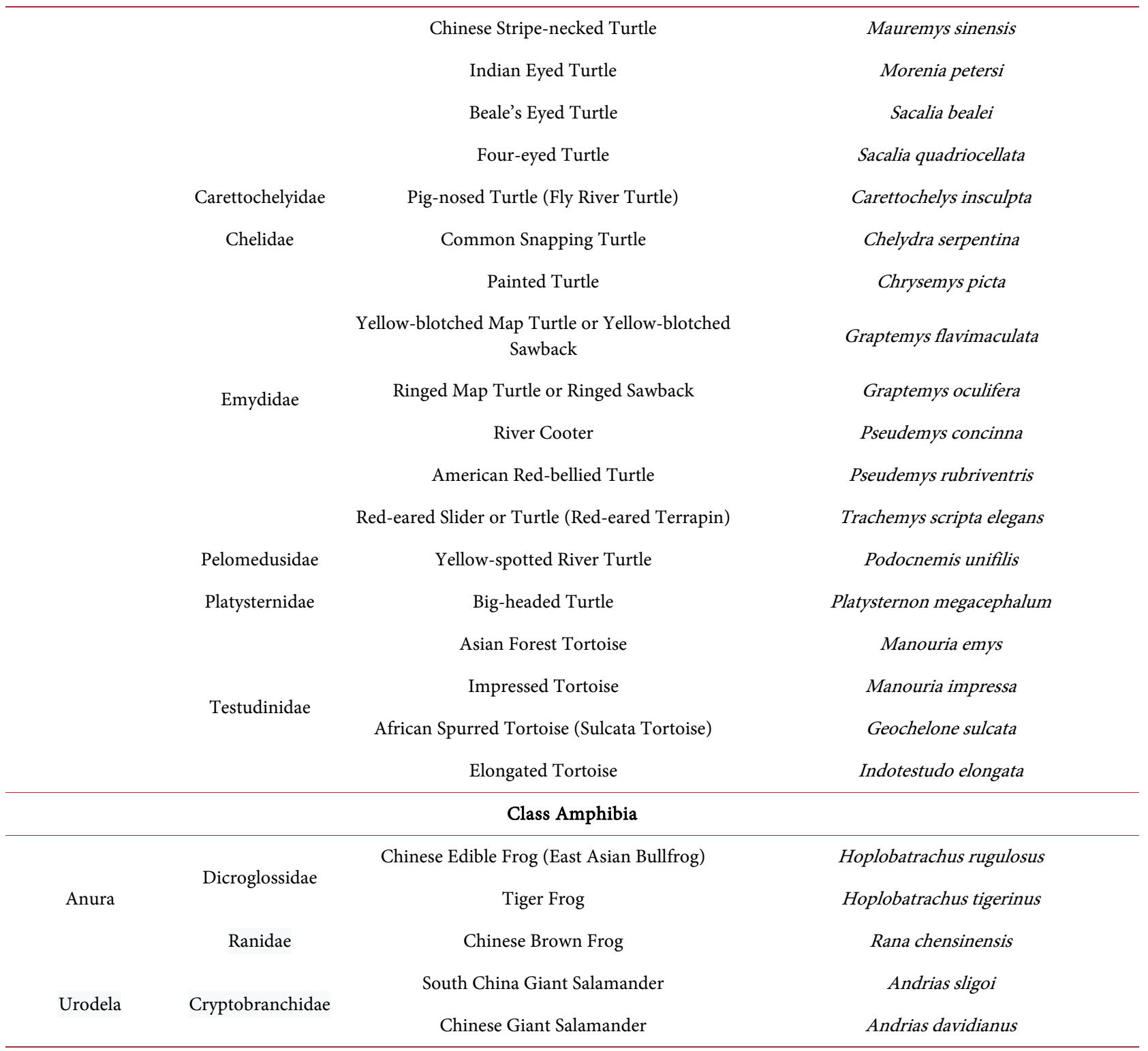

\subsection{Exploitation of Wildlife Resources}

During the COVID-19 outbreak and the accompanied quarantine measures, a lot of people have lost their livelihood. Social safety nets are a widespread feature of many industrialized economies, keeping the poor and vulnerable people from destitution. In many low-income countries, people simply do not have such back-up from their governments, leaving them incredibly vulnerable. Exploiting natural resources is often the only option for the destitute. The longer the COVID-19 outbreak lasts, many more people will be finding themselves poorer, hungrier, and much closer to exploitable wildlife than they were in the nearest past time. In a few words, when people are left with nothing, they can always find something to eat or sell in the wild; either being forests or oceans. In the Gaza Strip of Palestine, which has been under siege imposed by the Israeli occu- 
pation for more than a decade, the operations of poaching and hunting of wildlife, especially wild birds, by poor Gazans have increased. Wildlife hunting was not limited to food purposes, but rather to raising them as pets or to selling them to zoos that abounded in recent years in the Gaza Strip as a way to entertain the Gazans suffering from siege and repeated Israeli wars and invasions [32] [33] [34] [35] [36]. In the same context, the Palestinians of the West Bank of Palestine have been found, during the COVID-19 outbreak, to threaten the breeding success of the Chukar Partridge (Alectoris chukar) (Figure 4) and other breeding bird fauna. They search for nests and confiscate eggs, either for trade or food [33] [34] [35] [36] [37]. Such practices lead to reducing the numbers of these birds in the wild and constituting an obstacle to the ecological balance, as these birds contribute to reducing the number of insect pests harmful to agricultural crops.

\subsection{Reduction of Noise Pollution Benefits Wildlife}

Worldwide, human development introduces anthropogenic noise sources into the environment across many elements of the modern terrestrial landscape, including roads, airports, military bases, and cities. Cities and towns are very noisy places, with their transportation systems seem to be the most pervasive sources of noise across all landscapes. According to Blickley and Patricelli [38], noise can impact wildlife species at both the individual and population levels. The types of impacts include damage to auditory system, masking of sounds important to survival and reproduction, imposition of chronic stress and associated physiological responses, startling, interference with mating, and population declines. Noise is well-known to affect how different species communicate with each other [39]. Francis and Barber [40] pointed out that chronic and frequent noise interferes with animals' abilities to detect important sounds, whereas intermittent and unpredictable noise is often perceived as a threat. During the COVID-19 outbreak and the accompanied quarantine measures, there is a reduced traffic noise. Such reduction in noise may lower the impact of noise on wildlife health and ecology and offer better communication and mating opportunities among the wild biota.

\subsection{Breeding Success of Wildlife}

Wildlife species, particularly birds, usually carefully chose their breeding spots that are rarely disturbed by humans and predators. Such safe breeding places can be available during lockdowns associated with COVID-19 outbreak. As an example of breeding wildlife, the Little Tern (Sternula albifrons), a rarer seabird in the UK (Great Britain), is a vulnerable species that usually attempt to breed in the UK (Figure 5) in areas under public pressure, particularly holiday beaches [41] [42]. It is the smallest of the five tern species that breed in the UK. It lays camouflaged eggs on the beach, often close to the high water line. Human disturbance, primarily as an unintentional result of recreation activity, is thought to 
have been a major cause of reduced breeding success. The predation from foxes, kestrels, carrion crows and magpies is widely reported to cause colony failure or at least severe reduction to breeding success [41]. The breeding success (nest and hatching success) of the Little Tern could be threatened as dog walkers and other people flock to beaches once restrictions of COVID-19 outbreak are lifted, potentially trampling and disturbing breeding pairs and their young.

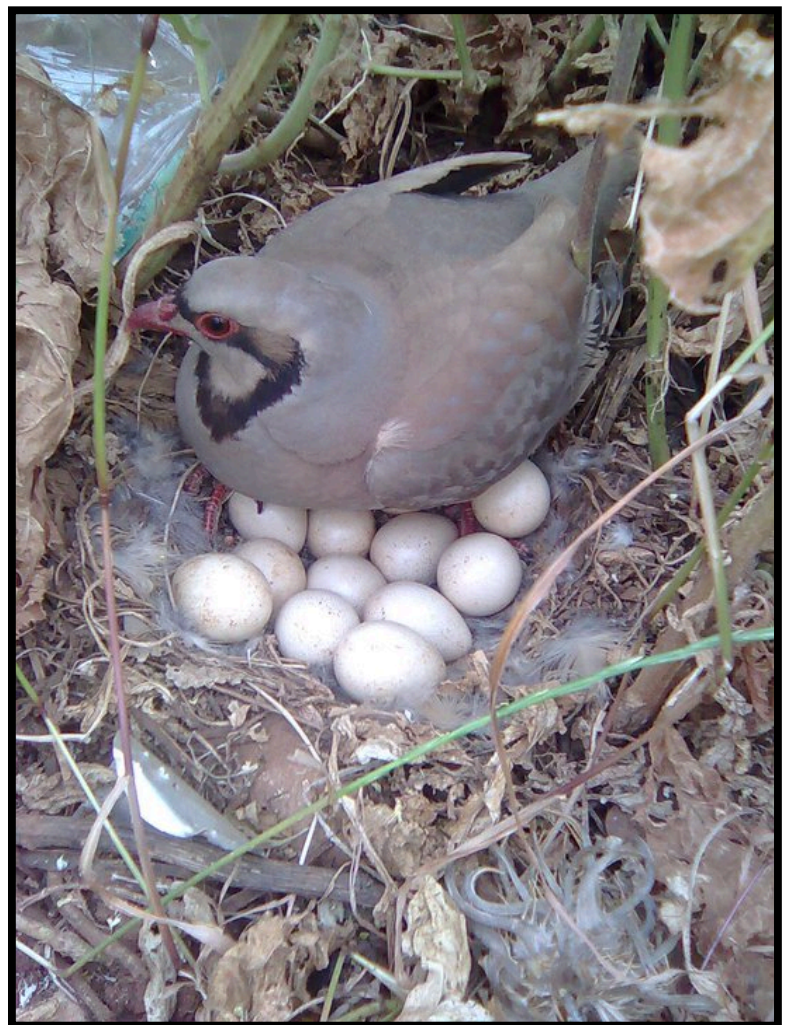

Figure 4. Poaching of the Chukar Partridge (Alectoris chukar) and the collection of its eggs increased during the COVID-19 outbreak in the West Bank of Palestine.

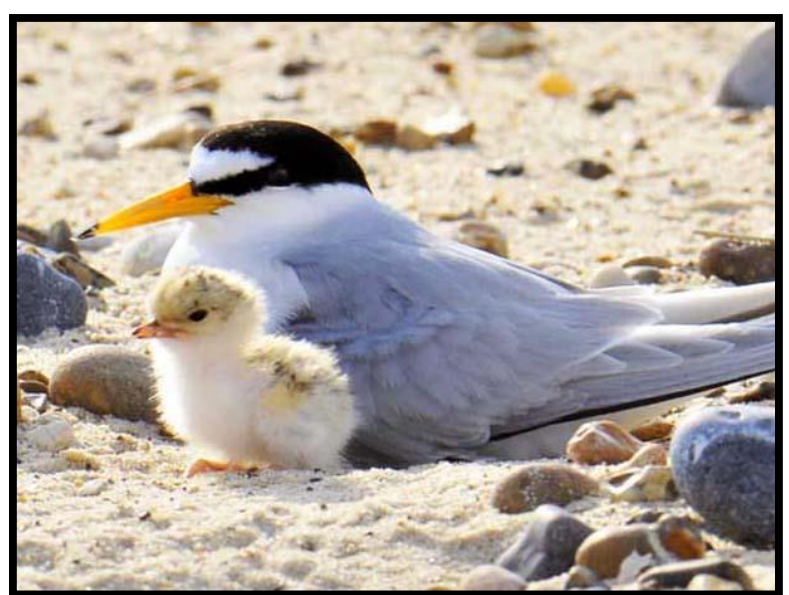

Figure 5. The breeding of the Little Tern (Sternula albifrons) on UK beaches. 
Another example showing the increase in bird populations during the COVID-19 outbreak and lockdown is the Albania's Pink Flamingo or what is known scientifically as the Greater Flamingo (Phoenicopterus roseus). These birds are recently flourishing at Narta Lagoon, an important waterfowl habitat in Albania, coinciding with the complete isolation witnessing Albania like the rest of the countries during the COVID-19 outbreak. The numbers have increased by nearly a third up to some 3000 since January of 2020. Albanian researchers plan to study flamingos to see if the coronavirus-induced calm is conducive to establishing the Narta Lagoon as a place where they can nest and breed. With less human interference and light pollution during COVID-19 outbreak, sea turtles, as endangered species, across the world are daring to lay their eggs on beaches they once avoided. For the first time in around a decade, Olive Ridley Turtles (Lepidochelys olivacea) can nest off the coast of the Bay of Bengal, India [43].

\subsection{Reduction of Wildlife Roadkills}

The development of roads and highways was known to affect wildlife by altering and isolating ecological habitats and populations, deterring and restricting the movement of wildlife, and resulting in extensive wildlife mortalities. Road traffic affects the natural environment in numerous ways. The most striking of these is the death of wild animals, including mammals, birds, reptiles, amphibians and invertebrates as a result of collisions with moving cars and other transportation motor vehicles [44] [45] [46]. The term "roadkills" means the animals struck and killed by cars and other transportation vehicles on roads and highways. Very large numbers of wild animals are killed on the world's roads every day [47]. About 350,000 to 27 million birds are estimated to be killed on European roads each year [48]. In Sweden, ungulates (mammals having hooves) were of primary concern, as they accounted for more than $60 \%$ of the accidents registered by the police [49]. In fact, wildlife mortality on roads is a problematic with profound deleterious effects, including reductions in population sizes, increases in local extinction, and loss of ecosystemic functionality. These numbers of wildlife-vehicle collisions are highly expected to diminish because of the lockdown of cities and towns during COVID-19 outbreak. In simple words, fewer cars on the road mean less roadkills. This may explain the encroachment of many wildlife species, as stated before, into the deserted cities and towns during the current COVID-19 outbreak. The fewer transportation vehicles and people promote such a wildlife safety from collisions and traffic accidents.

\subsection{Shortage of Food Provided to Wild and Zoo Animals}

Many wildlife species in local zoos and parks like primates, ducks and geese rely on foods provided by humans including tourists. The current close of zoos and parks and other similar places to the public during COVID-19 outbreak may make many animals to seeking new sources of food. Many news websites claimed that the German zoos are in struggle for survival because of closures re- 
sulted from COVID-19 outbreak and its quarantine measures. Because of zoo's financial crisis, the directors pointed out that the zoos may have to feed some of their animals to the flesh of other animals from its inmates, and there was a screening for animals to be slaughtered before others. The directors added that seals and penguins and many other zoo animals need large quantities of fresh fish and food every day and they may have to kill the animals for mercy with them, instead of letting them die of hunger. From another point of view, the current COVID-19 crisis has had emotional repercussions for some animals like monkeys, gorillas, otters, seals, Giant Pandas and parrots that yearn for the attention they receive from the public (Figure 6). It is worth mentioning that visitors can have either negative, neutral or positive impacts on zoo animal behavior and welfare. Sherwen and Hemsworth [50] pointed out that the variation of zoo animal's responses to visitors may be associated with several factors including the species-specific differences, the nature and intensity of the visitor interactions, differences in the physical features of enclosures, and individual animal characteristics.

Because of the worldwide COVID-19 outbreak, city-dwelling rodents find themselves unable to dine out on restaurant waste, street garbage and other food sources. There was an increase in rodent activity as rodents search for new sources of food. According to Helmore [51], complaints in Chicago, USA, have included reports of infestations in housing blocks as rodents seek new sources of food. Many rat species have been observed resorting to eating their young in the wake of urban shutdowns in the USA.

\subsection{Fish Biomass Increase as a Consequence of COVID-19}

In most coastal countries of the world, safety rules designed to stop the spread of COVID-19 virus, coupled with reduced demand because of unemployment and closed restaurants, have forced fishing fleets and vessels to stay in ports and harbors [52]. As a result, fish biomass was expected to increase because of the sharp decline in fishing activities [53]. It is well known that overfishing is an escalating environmental issue threatening fisheries resources all over the world, even in the Gaza Strip of Palestine in spite of its small marine area [54]. Overfishing has reduced the stocks of many predator fishes in the Mediterranean Sea by high percentages compared to their pre-industrial fishing populations. As a consequence of COVID-19 lockdowns, some fish species are expected to double their biomass.

\subsection{Wildlife Saves Humankind from COVID-19}

Current research reports announced that there is a success in isolating an antibody from a four-year-old female Llama (Lama glama) living in a Belgian farm, suggesting that it would form a barrier against COVID-19. It was claimed that this antibody can make the COVID-19 virus harmless. The antibody molecule was said to be found in camels and alpacas in addition to sharks. It is worth mentioning that the Llama (Figure 7) are very social animal belonging to Came- 
lidae family and Artiodactyla order of mammals. In this context, it was found that cats-though they are domestic-are more susceptible to infection with coronaviruses, making them ideal for testing against COVID-19 vaccines.

\subsection{Infection of Wild and Pet Animals with COVID-19}

There is a possibility for some pet or wild animals to become infected with COVID-19 virus through close contact with infected humans. Several dogs, ferrets, cats (including tigers and domestic cats) and even Egyptian Fruit-bats have tested positive to COVID-19 virus following close contact with infected humans. According to a recent study, the media of Aljazeera pointed out that cats can easily get infected with COVID-19 virus and even transmit the infection between them. In New York State of USA, current tests on two pet cats confirmed they were infected with COVID-19, in what were the first two cases of pets in the USA [55]. Tests have previously shown the infection of seven lions and tigers (feline family) with COVID-19 in the Bronx Zoo in New York. It is worth mentioning that infection of animals with COVID-19 virus may have implications for animal health and welfare, and for wildlife conservation.

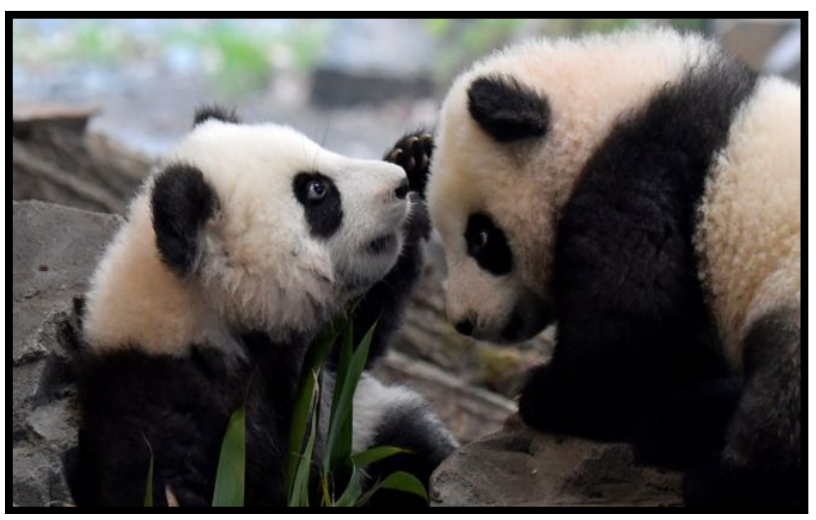

Figure 6. Zoo animals, like the Giant Panda (Ailuropoda melanoleuca), are missing human attention because of closures imposed by COVID-19 outbreak.

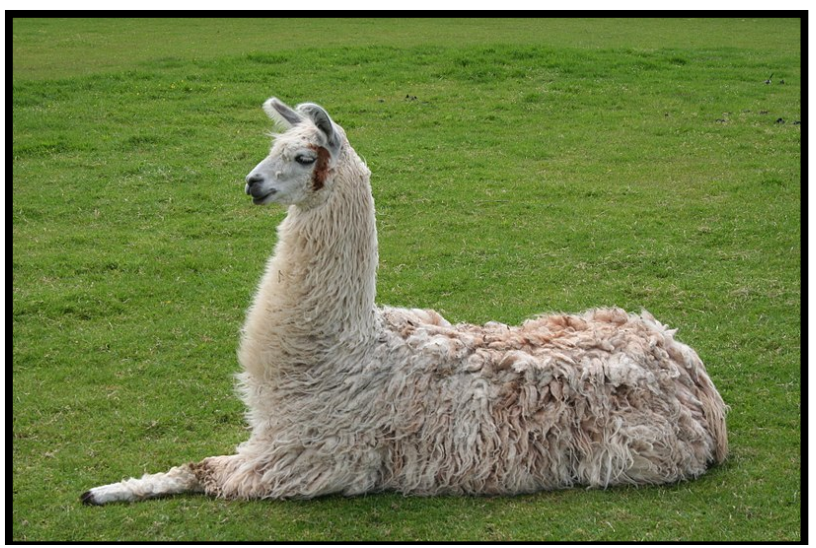

Figure 7. The Llama (Lama glama) may save humankind from COVID-19. 
In a strange event that occurred in India, a troop of monkeys attacked a lab technician at a government hospital in the Meerut district of the north Indian state of Uttar Pradesh and stole sample boxes containing blood samples of patients who were found to be infected with COVID-19. The monkeys climbed the trees with the samples and threw them after chewing the packets. It was said that the sample boxes were recovered at a later time without any damage or any risk of contamination or spread of infection. The hospital authorities have sanitized the area and disposed of the samples snatched by the monkeys. The district administration has ordered an inquiry against the hospital authorities for alleged mishandling of the samples [56]. The question here, which needs a scientific interpretation, is what would happen if monkeys messed with blood samples or consumed them orally?

\subsection{Connection with Nature and Wildlife}

School and university closures during the lockdown of cities and towns because of COVID-19 outbreak were a common phenomenon in most countries worldwide. Such closures may enhance many people to use their time and own skills to connect with nature in their own backyards and surrounding environments. Activities done by people and even children in gardens and parks like making bird feeders or birding (bird watching) could help encourage nature close to home. The connection with wildlife may contribute to important scientific research.

\section{Concluding Remarks}

In conclusion, the regulation of native and exotic animal trade in wildlife or wet markets is of utmost priority in order to lower the incidence of COVID-19 and other zoonoses. Such regulations should be accompanied with public education and awareness campaigns focusing on the need to prevent new diseases by reducing demand for wildlife and its products.

\section{Acknowledgements}

My thanks are due to Ms. Eqbal S. Radwan, Mr. Ismail S. Radwan, Mr. Bashar S. Jarayseh and Mr. Mohammed A. Abd Rabou for their continuous help with technical support throughout the current study.

\section{Conflicts of Interest}

The author declares no conflicts of interest regarding the publication of this paper.

\section{References}

[1] Guan, Y., et al. (2003) Isolation and Characterization of Viruses Related to the SARS Coronavirus from Animals in Southern China. Science, 302, 276-278. https://doi.org/10.1126/science.1087139 
[2] Shereen, M.A., Khan, S., Kazmi, A., Bashir, N. and Siddique, R. (2020) COVID-19 Infection: Origin, Transmission, and Characteristics of Human Coronaviruses. Journal of Advanced Research, 24, 91-98. https://doi.org/10.1016/j.jare.2020.03.005

[3] Wang, C., Horby, P.W., Hayden, F.G. and Gao, G.F. (2020) A Novel Coronavirus Outbreak of Global Health Concern. The Lancet, 395, 470-473. https://doi.org/10.1016/S0140-6736(20)30185-9

[4] Altaf, M. (2020) Wild Animals as Source of Zoonotic Diseases-A Review. Journal of Wildlife and Ecology, 4, 71-84.

[5] Cui, J., Li, F. and Shi, Z.-L. (2019) Origin and Evolution of Pathogenic Coronaviruses. Nature Reviews Microbiology, 17, 181-192.

https://doi.org/10.1038/s41579-018-0118-9

[6] Yin, Y.D. and Wonderlink, R.G. (2018) MERS, SARS and Other Coronaviruses as Causes of Pneumonia. Respirology, 23, 130-137.

https://doi.org/10.1111/resp.13196

[7] Lu, H.Z., Stratton, C.W. and Tang, Y.-W. (2020) Outbreak of Pneumonia of Unknown Etiology in Wuhan, China: The Mystery and the Miracle. Journal of Medical Virology, 92, 401-402. https://doi.org/10.1002/jmv.25678

[8] Christ, C., Hillel, O., Matus, S. and Sweeting, J. (2003) Tourism and Biodiversity: Mapping Tourism Global Foot Print. Conservation International, Washington DC, $66 \mathrm{p}$.

[9] Mulualem, G. and Tesfahunegny, W. (2016) Review of Key Wildlife Threats Factors from Literature and Observation Perspectives, a Way Forward for Sustainable Wildlife Genetic Resource Conservation Practices in Ethiopia. The Journal of Zoology Studies, 3, 1-12.

[10] Lowry, T. and Smith, S.A. (2007) Aquatic Zoonoses Associated with Food, Bait, Ornamental, and Tropical Fish. Journal of the American Veterinary Medical Association, 231, 876-880. https://doi.org/10.2460/javma.231.6.876

[11] Cantlay, J.C., Ingram, D.J. and Meredith, A.L. (2017) A Review of Zoonotic Infection Risks Associated with the Wild Meat Trade in Malaysia. EcoHealth, 14, 361-388. https://doi.org/10.1007/s10393-017-1229-x

[12] Li, W., et al. (2005) Bats Are Natural Reservoirs of SARS-Like Coronaviruses. Science, 310, 676-679. https://doi.org/10.1126/science.1118391

[13] Zhai, S.L., Wei, W.K., Lv, D.H., Xu, Z.H., Chen, Q.L., Sun, M.F. and Wang, D. (2020) Where Did SARS-CoV-2 Come From? Veterinary Record, 186, 254-254. https://doi.org/10.1136/vr.m740

[14] Zhang, T., Wu, Q. and Zhang, Z. (2020) Probable Pangolin Origin of SARS-CoV-2 Associated with the COVID-19 Outbreak. Current Biology, 30, 1346-1351. https://doi.org/10.1016/j.cub.2020.03.022

[15] Lam, T.T., Shum, M.H., Zhu, H., Tong, Y., Ni, X., Liao, Y., Wei, W., Cheung, W.Y., Li, W., Li, L., Leung, G.M., Holmes, E.C., Hu, Y. and Guan, Y. (2000) Identification of 2019-nCoV Related Coronaviruses in Malayan Pangolins in Southern China. Nature, 583, 282-285.

[16] Akrim, F., Mahmood, T., Hussain, R., Qasim, S., et al. (2017) Distribution Pattern, Population Estimation and Threats to the Indian Pangolin Manis crassicaudata (Mammalia: Pholidota: Manidae) in and around Pir Lasura National Park, Azad Jammu \& Kashmir, Pakistan. Journal of Threatened Taxa, 9, 9920-9927. https://doi.org/10.11609/jott.2914.9.3.9920-9927

[17] Challender, D.W.S., Waterman, C. and Baillie, J.E.M. (2014) Scaling up Pangolin Conservation. IUCN SSC Pangolin Specialist Group Conservation Action Plan, 
Zoological Society of London, London, $21 \mathrm{p}$.

[18] Heath, M.E. (1992) Manis Pentadactyla. Mammalian Species, No. 414, 1-6. https://doi.org/10.2307/3504143

[19] Pantel, S. and Chin, S.Y. (2009) Proceedings of the Workshop on Trade and Conservation of Pangolins Native to South and Southeast Asia. Workshop on Trade and Conservation of Pangolins Native to South and Southeast Asia, Singapore Zoo, Singapore, 30 June-2 July 2008, 227 p.

[20] Gomez, L., Leupen, B.T.C. and Heinrich, S. (2016) Observations of the Illegal Pangolin Trade in Lao PDR. TRAFFIC, Southeast Asia Regional Office, Petaling Jaya, Selangor, Malaysia, $21 \mathrm{p}$.

[21] Iftkhar, A., Umair, M., Abbasi, A., Ashraf, S., Bashir, S.M., Afsheen, S., Aslam, H., Ijaz, S. and Adil, S. (2018) Status and Cultural Uses of Indian Pangolin (Manis crassicaudata) in Selected Sites of Pakistan. Journal of Wildlife and Ecology, 2, 23-30.

[22] Andersen, K.G., Rambaut, A., Lipkin, W.I., Holmes, E.C. and Garry, R.F. (2020) The Proximal Origin of SARS-CoV-2. Nature Medicine, 26, 450-452. https://doi.org/10.1038/s41591-020-0820-9

[23] Agence France-Presse (2020) Coronavirus, Wild Animals Take Back World's Empty City Streets as People Stay Indoors. South China Morning Post.

https://www.scmp.com/news/world/article/3077518/coronavirus-wild-animals-take -back-worlds-empty-city-streets-people-stay

[24] Garcia, S.E. (2020) When Humans are Sheltered in Place, Wild Animals Will Play. The New York Times. https://www.nytimes.com/2020/04/01/science/coronavirus-animals-wildlife-goats.h $\underline{\mathrm{tml}}$

[25] Khalaf, N.A.B. (2020) Wildlife Rewilding Dubai and Abu Dhabi during Coronavirus COVID-19 Pandemic Lockdown. Gazelle the Palestinian Biological Bulletin, 199, $1-16$.

[26] Altaf, M. (2017) First Record of Small Indian Civet (Viverricula indica) from Azad Jammu and Kashmir Himalaya, Pakistan. Journal of Wildlife and Ecology, 1, 17-24.

[27] Li, Y.M. and Li, D.M. (1998) The Dynamics of Trade in Live Wildlife across the Guangxi Border between China and Vietnam during 1993-1996 and Its Control Strategies. Biodiversity \& Conservation, 7, 895-914. https://doi.org/10.1023/A:1008873119651

[28] Li, Y.-M., Gao, Z.X., Li, X.H., Sung, W. and Niemela, J. (2000) Illegal Wildlife Trade in the Himalayan Region of China. Biodiversity \& Conservation, 9, 901-918. https://doi.org/10.1023/A:1008905430813

[29] Chow, A.T., Cheung, S. and Yip, P.K. (2014) Wildlife Markets in South China. Human- Wildlife Interactions, 8, 108-112.

[30] Humane Society International (2020) Wildlife Markets and COVID-19. Washington DC, USA, $19 \mathrm{p}$.

[31] McCall, R. (2020) Eating Bats and Pangolins Banned in Gabon as a Result of Coronavirus Pandemic.

https://www.newsweek.com/eating-bats-pangolins-gabon-coronavirus-pandemic-1 496329

[32] Abd Rabou, A.N. (2009) On the Occurrence of Some Carnivores in the Gaza Strip, Palestine (Mammalia: Carnivora). Zoology in the Middle East, 46, 109-112. https://doi.org/10.1080/09397140.2009.10638336

[33] Abd Rabou, A.N. (2011) On the Ecology of Wadi Gaza, Gaza Strip, Survey and As- 
sessment: Wildlife Is Focused. LAP LAMBERT Academic Publishing, Germany, 332 p.

[34] Abd Rabou, A.N. (2011) The Palestinian Mammalian Fauna Acquired by the Zoological Gardens in the Gaza Strip. Nusantara Bioscience, 3, 82-91.

[35] Abd Rabou, A.N. (2019) Ornithofauna Prevailing at Al-Mawasi Ecosystem of the Gaza Strip, Palestine. Open Journal of Ecology, 9, 360-400. https://doi.org/10.4236/oje.2019.99025

[36] Abd Rabou, A.N. (2019) The Mammalian, Reptilian and Amphibian Fauna of Al-Mawasi Ecosystem, South-Western Gaza Strip-Palestine. Agricultural Research \& Technology, 23, Article ID: 556234.

[37] Abd Rabou, A.N. (2005) An Ecological Survey and Assessment of Wadi Gaza Nature Reserve, Gaza Strip-Palestine, with Particular Emphasis on Wildlife. Ph.D. Thesis, Al-Neelain University, Sudan, 278 p.

[38] Blickley, J.L. and Patricelli, G.L. (2010) Impacts of Anthropogenic Noise on Wildlife: Research Priorities for the Development of Standards and Mitigation. Journal of International Wildlife Law \& Policy, 13, 274-292. https://doi.org/10.1080/13880292.2010.524564

[39] Kight, C.R. and Swaddle, J.P. (2011) How and Why Environmental Noise Impacts Animals: An Integrative, Mechanistic Review. Ecology Letters, 14, 1052-1061. https://doi.org/10.1111/j.1461-0248.2011.01664.x

[40] Francis, C.D. and Barber, J.R. (2013) A Framework for Understanding Noise Impacts on Wildlife: An Urgent Conservation Priority. Frontiers in Ecology and the Environment, 11, 305-313. https://doi.org/10.1890/120183

[41] Pickerell, G. (2004) Little Tern Sterna albifrons. In: Mitchell, P.I., Newton, S., Ratcliffe, N. and Dunn, T.E., Eds., Seabird Populations of Britain and Ireland, Poyer, London, 339-449.

[42] Parsons, M., Lawson, J., Lewis, M., Lawrence, R. and Kuepfer, A. (2015) Quantifying Foraging Areas of Little Tern around Its Breeding Colony SPA during Chick-Rearing. Joint Nature Conservation Committee, Peterborough, Britain, 27 p.

[43] Euronews Living with AP (2020) While You Stay Home, Animals Roam Free in Our Towns and Cities.

https://www.euronews.com/living/2020/04/25/while-you-stay-home-animals-roamfree-in-our-towns-and-cities

[44] Trombulak, S.T. and Frissell, C.A. (2000) Review of Ecological Effects of Roads on Terrestrial and Aquatic Communities. Journal of Biological Conservation, 14, 18-30. https://doi.org/10.1046/j.1523-1739.2000.99084.x

[45] Albaba, E.M. (2017) Surveying Wildlife Roadkills in the West Bank Governorates-Palestine. Journal of Entomology and Zoology Studies, 5, 910-913.

[46] Coelho, I.P., Kindel, A. and Coelho, A.V.P. (2008) Roadkills of Vertebrate Species on Two Highways through the Atlantic Forest Biosphere Reserve, Southern Brazil. European Journal of Wildlife Resources, 54, Article No. 689. https://doi.org/10.1007/s10344-008-0197-4

[47] Ashley, E.P. and Robinson, J.T. (1996) Road Mortality of Amphibians, Reptiles and Other Wildlife on the Long Point Causeway, Lake Erie, Ontario. Canadian Field Naturalist, 110, 403-412.

[48] Erritzoe, J., Mazgajski, T.D. and Rejt, Ł. (2003) Bird Casualties on European Roads-A Review. Acta Ornithologica, 38, 77-93.

https://doi.org/10.3161/068.038.0204 
[49] Seiler, A. (2004) Trends and Spatial Patterns in Ungulate-Vehicle Collisions in Sweden. Wildlife Biology, 10, 301-313. https://doi.org/10.2981/wlb.2004.036

[50] Sherwen, S.L. and Hemsworth, P.H. (2019) The Visitor Effect on Zoo Animals, Implications and Opportunities for Zoo Animal Welfare. Animals, 9, 366-392. https://doi.org/10.3390/ani9060366

[51] Helmore, E. (2020) CDC Warns of Aggressive Cannibal Rats Facing Shortage of Garbage to Eat (25 May 2020). The Guardian.

https://www.theguardian.com/world/2020/may/25/us-city-lockdowns-rat-aggressio n-lack-food-waste

[52] Korten, T. (2020) With Boats Stuck in Harbor Because of COVID-19, Will Fish Bounce Back? Smithsonian Magazine.

https://www.smithsonianmag.com/science-nature/fish-stop-covid-19-180974623/

[53] Reiley, L. (2020) Commercial Fishing Industry in Free Fall as Restaurants Close, Consumers Hunker Down and Vessels Tie up. The Washington Post. https://www.newsbreak.com/news/1543252081135/commercial-fishing-industry-infree-fall-as-restaurants-close-consumers-hunker-down-and-vessels-tie-up

[54] Abd Rabou, A.N. (2013) Priorities of Scientific Research in the Fields of Marine Environment and Fishery Resources in the Gaza Strip-Palestine. Priorities of Scientific Research in Palestine: Towards a National Directory of Scientific Research, Scientific Research Affairs, Islamic University of Gaza, Gaza Strip, Palestine, 25-26 March 2013, 481-522.

[55] Peltz, J. (2020) 2 Cats in NY Become the First US Pets to Test Positive for Virus. AP News. https://apnews.com/37328ab8db093b8346e26e1840b48af8

[56] Pratap, R.M. and Gupta, S. (2020) Monkeys Snatch Blood Samples of Suspected Covid-19 Patients in India.

https://edition.cnn.com/2020/05/29/india/monkey-samples-covid-19-india-intl-scli/ index.html 